M. Đ. Učur*

\title{
PITANJA I ODNOSI POSLJEDICA IZLOŽENOSTI RIZIKU RADA S AZBESTOM
}

UDK 613.632.2:679.867

PRIMLJENO: 31.3 .2020 .

PRIHVAĆENO: 3.7 .2020

Ovo djelo je dano na korištenje pod Creative

Commons Attribution 4.0 International License

SAŽETAK: U brojnim trgovačkim društvima (poduzećima) u proizvodnji, odnosno u realizaciji registrirane djelatnosti korišten je azbest pa su radnici radeći kod tih poslodavaca bili izloženi riziku posljedica toga i takvoga rada. Za neke od tih radnika posljedice su pogubne jer su oboljeli od azbestoze i drugih bolesti. Mnogi poslodavci prestali su s radom, a pravni sljednici, neki od njih, od 2005. godine i ne obavljaju djelatnost u kojoj se upotrebljava azbest jer je zabranjen. Ozbiljan je problem (veliki broj socijalnih slučajeva) kako obeštetiti (ako je uopće moguće) radnike koji su bili izloženi azbestu. Države se javljaju kao „jamac" isplate novčanih naknada kao oblika obeštećenja. Na to Republiku Hrvatsku obvezuju nacionalni i regionalni propisi (konvencije MOR-a, direktive EU-a), ali i nacionalni propisi o tim pitanjima i odnosima. Propisi su na snazi i primjenjuju se u složenom i zahtjevnom postupku. Razlozi financijske naravi determiniraju rješavanje tih pitanja, a posljedice se javljaju i nakon 30 pa i 40 godina od izloženosti radnika riziku rada s azbestom. Predmet ovoga rada ukazuje na težinu društvenih $i$ pravnih odnosa i pitanja.

Ključne riječi: izloženost azbestu, posljedice, obeštećenje, propisi i odnosi

\section{UVOD}

Obeštećenje radnika „zbog višegodišnje izloženosti azbestu" uređuje zakon. Sada je to "zaseban slučaj" uređen za "bivše radnike trgovačkog društva Plobest d.d. Ploče". ${ }^{1}$ Dok Zakon o obeštećenju radnika profesionalno izloženih azbestu „uređuje priznavanje odštetnih zahtjeva radnika oboljelih od bolesti uzrokovanih azbestom", Zakon o obeštećenju radnika trgovačkog društva Plobest d.d. „uređuje obeštećenje radnika“ u tom poduzeću „zbog višegodišnje izloženosti azbestu". Razlika je uočljiva već u naslovu, a pogotovo u sadržaju. U Zakonu o obeštećenju radnika profesionalno izloženih azbestu riječ je o radnicima „koji su oboljeli od bolesti uzroko-

*Prof. dr. sc. Marinko Đ. Učur, dipl. pravnik, znanstveni savjetnik (u trajnom zvanju) iz Rijeke, (marinko.ucur051@gmail.com), 51000 Rijeka.

'Zakon o obeštećenju radnika profesionalno izloženih azbestu - N.N., br. 79/07., 139/10., 111/18.; Zakon o obeštećenju radnika trgovačkog društva Plobest d.d. - N.N., br. 13/20. vanih azbestom", dok Zakon o obeštećenju radnika t.d. Plobest d.d. „traži“ da je radnik bio „u radnom odnosu" u točno određenom društvu i u točno određenom vremenu (a ne govori se da je "obolio" od bolesti uzrokovanih azbestom). Prema tome, obolijevanje od bolesti uzrokovane azbestom nije uvjet za dobivanje odštete prema ovom Zakonu.

To je samo neposredan povod za priznanje radnicima koji su bili u radnom odnosu i pri radu bili izloženi azbestu, odnosno koji su oboljeli od profesionalnih i drugih bolesti zbog toga. Rad s azbestom je zabranjen, ali su "ostali“ radnici koji su mu bili izloženi najčešće s neotklonjivim posljedicama. Nažalost, veliki broj "bivših" radnika nije ostvario nikakvu naknadu u obliku obeštećenja (zbog smrti ili zbog propisanog postupka) ${ }^{2}$.

${ }^{2}$ Prema Zakonu o obeštećenju radnika t.d. Salonit d.d. u stečaju Vranjic (N.N., br. 84/11.), priznato je obeštećenje za 170 radnika. U obrazloženju Zakona piše da je „55 osiguranika umrlo“ bez prava na obeštećenje 2019. (Hrv. sabor, P.Z. 642, Zagreb, 12.12.2019.). 
To govori da je kasno za najveći broj radnika koji su godinama radeći bili izloženi azbestu kod poslodavaca koji su zakonito obavljali registriranu djelatnost u građevinskoj industriji, automobilskoj industriji, u brodogradnji, metalurgiji i drugima u Republici Hrvatskoj dok je azbest bio u primjeni. ${ }^{3}$ Sve dok se javljaju posljedice izloženosti azbestu radnici imaju pravo na odštetu zbog toga. Prema Zakonu o obeštećenju radnika profesionalno izloženih azbestu radnici imaju pravo na obeštećenje zbog bolesti trajno i zakon je jamstvo da će dobiti obeštećenje ako se razbole bez obzira na protok vremena. Taj broj je teško odrediti jer se posljedice javljaju i 40 godina od izloženosti azbestu. Jamstvo za njih mora postojati bez obzira donose li se „posebni zakoni" za konkretne poslodavce i radnike. To, pogotovo, što dolazi vrijeme uklanjanja krovova i drugih objekata „punih“ azbesta (rušenje, lomljenje, rezanje, bušenje, skladištenje i slično), a onda slijede posljedice.

Dana 1.1.2005. stupila je na snagu Direktiva 1999/77/EU o sveobuhvatnoj zabrani korištenja i marketinga proizvoda koji sadrže azbest.

Izostalo je preventivno djelovanje svih subjekata koji su izravno ili neizravno bili "uključeni" $\mathrm{u}$ procese (odnose) rada $\mathrm{s}$ azbestom u brojnim djelatnostima i kod brojnih poslodavaca. Zdravstvena struka u Hrvatskoj se oglasila još 1961. godine objavljujući rad o bolestima uzrokovanih azbestom (Azbestoza u tvornici azbestno-cementnih proizvoda). Sada se plaća skupi "ceh", a novi propisi to ne mogu sanirati već samo neznatno ublažiti.

\section{POJMOVI I PROPISI}

U "registru“ propisa pojam "azbest" povezan je sa: „zaštitom radnika od rizika za njihovo zdravlje; gospodarenjem otpadom; starosnom mirovinom radnika izloženih azbestu; obeštećenjem radnika izloženih azbestu; zdravstvenim nadzorom radnika izloženih azbestu i konvencijama o sigurnosti prilikom uporabe azbesta".

${ }^{3}$ Od početka pedesetih godina u Hrvatskoj se godišnje povremeno preradilo i u proizvodnji koristilo i do 60.000 tona azbesta... Prvi slučajevi azbestoze pluća "otkriveni" su u RH 1961. godine ("Obrazloženje" P.Z. br. 642 - cit. str. 3.). Od 1990. do 2015 registrirano je 1.517 oboljelih od profesionalnih bolesti kao posljedice izloženosti azbestu (Hrvatski sabor, Sjednica 10, 28.11.2018.).
Određene znanstvene discipline definiraju pojam azbesta, uporabu, zaštitu i druga pitanja i odnose. Propisi različitog naziva, donositelja, vremenskog i prostornog važenja svojim sadržajem na odgovarajući način utvrđuju pitanja azbesta i odnosa koji u vezi s tim nastaju.

Brojna trgovačka društva u Republici Hrvatskoj registrirana su da unutar svoje djelatnosti mogu obavljati poslove zaštite na radu (zaštita zdravlja i sigurnosti na radu).

Nadzor u primjeni propisa u zaštiti na radu u poslovima s azbestom obavlja inspekcija u sklopu Državnog inspektorata nakon što se prestao primjenjivati Zakon o Inspektoratu rada. ${ }^{4}$

Rad s azbestom je poseban, specifičan, opasan i u pravilu zabranjen. Može se reći da je "atipičan". ${ }^{5}$ Predmet je i individualnih radnih sporova. Uređen je prvenstveno heteronomnim pravnim normama (univerzalnog, regionalnog $\mathrm{i}$ nacionalnog) karaktera. Posredno se primjenjuju i propisi o „opasnim kemikalijama na radu“.

To su i propisi o: utvrđivanju opće i posebne zdravstvene sposobnosti radnika i sposobnosti radnika za obavljanje poslova s posebnim uvjetima rada; zaštiti na radu na mjestu rada; pružanju prve pomoći radnicima na radu, ispravama i evidencijama u zaštiti zdravlja i sigurnosti na radu i $\mathrm{dr}^{6}{ }^{6}$

Zakon o radu uređuje i zaštitu života, zdravlja i privatnosti radnika (dužnosti poslodavca u održavanju postrojenja, uređaja, opreme, alata, mjesta rada, organizacija rada i dr.). ${ }^{7}$

Poseban je Pravilnik o zaštiti radnika od rizika zbog izloženosti azbestu. ${ }^{8}$ Tu je i Pravilnik o poslovima s posebnim uvjetima rada, o pregledu $\mathrm{i}$ ispitivanju radne opreme; o ispitivanju radnog

\footnotetext{
${ }^{4}$ Zakon o Državnom inspektoratu - N.N., br. 173/18.; Zakon o Inspektoru rada - N.N., br. 19/14., Zakon o zaštiti na radu - N.N., br. 94/18., 96/18

${ }^{5} \mathrm{O}$ atipičnom radu piše LALETA, Sandra i SENČUR PEČEK, Darja, Sigurnost, 4/17., str. 315-330.

${ }^{6}$ Pravilnik o utvrđivanju opće i posebne zdravstvene sposobnosti radnika - N.N., br. 3/84., 55/85., Pravilnik o zaštiti na radu na mjestu rada - N.N., br. 29/13., Pravilnik o pružanju prve pomoći radnika na radu - N.N., br. 56/81. Vidi Zakon o zaštiti na radu - cit. članak 103.

${ }^{7}$ Zakon o radu - N.N., br. 93/14., 127/17., 98/19., članak 28. i 29.

${ }^{8}$ Pravilnik... - N.N., br. 40/07. Vidi Zakon o zaštiti na radu: članak 103 .
} 
okoliša; o zaštiti radnika radnika od rizika zbog izloženosti karcinogenima i/ili mutagenima i drugi. ${ }^{9}$

Posredno se primjenjuju i propisi o zaštiti od buke $^{10}$, propisi o odlaganju otpada, ambalaže, zaštiti okoliša, a neposredno Pravilnik o građevnom otpadu i otpadu koji sadrži azbest. ${ }^{11}$

Od 1. siječnja 2019. g. primjenjuju se izmjene i dopune Zakona o obeštećenju radnika profesionalno izloženih azbestu. ${ }^{12}$

Tako je i sa Zakonom o izmjenama i dopunama Zakona o obveznom zdravstvenom nadzoru radnika profesionalno izloženih azbestu. ${ }^{13}$ Pri tome se primjenjuje Pravilnik o uvjetima i načinu praćenja zdravstvenog stanja, dijagnostičkim postupcima kod sumnje na postojanje profesionalnih bolesti uzrokovanih azbestom te mjerilima za priznavanje profesionalne bolesti uzrokovane azbestom. ${ }^{14}$

Već su doneseni i na snazi su Zakon o obeštećenju radnika izloženih azbestu (npr. t. d. Salonit d.d. u stečaju Vranjic) ${ }^{15}$ te o uvjetima za stjecanje prava na starosnu mirovinu radnika profesionalno izloženih azbestu (a to je „i radnik koji je, radeći kod pravne osobe koja je u proizvodnji koristila azbest kao sirovinsku osnovu, obolio od bolesti uzrokovane azbestom...", a bolest se utvrđuje vještačenjem....). ${ }^{16}$

Profesionalna izloženost azbestu pored drugih jest predmet i sadržaj konvencija Međunarodne organizacije rada (MOR-a, ILO, OIT) i sekundarnih vrela prava Europske unije (EU). ${ }^{17}$

Zakon ima precizno (ali „usko“ i "kratko“) prostorno i vremensko važenje. ${ }^{18}$ Prigovara se i na je-

${ }^{9}$ Pravilnik... - N.N., br. 5/84., Zakon o zaštiti na radu - isto. Pravilnik... - N.N., br. „16/16.; Pravilnik... - N.N., br. 91/15.

${ }^{10}$ Zakon o zaštiti od buke... - N.N., br. 30/90. do 114/18.

${ }^{11}$ Pravilnik... - N.N., br. 69/16.

${ }^{12}$ Zakon... - N.N., br. 79/07. do 111/18.

${ }^{13}$ Zakon... - N.N., br. 79/07. do 111/18.

${ }^{14}$ Pravilnik...- N.N., br. 134/08.; vidi Zakon o stažu osiguranja s povećanim trajanjem - N.N., br. 115/18.

${ }^{15}$ Zakon... - N.N., br. 84/11.

${ }^{16}$ Zakon... - N.N., br. 79/07. do 139/10.

${ }^{17}$ Konvencija MOR-a broj 162. o sigurnosti prilikom uporabe azbesta (1986.); (N.N.- M.U., br. 11/03.); direktive EU 99/77/EC, 76/477/EEC, 183/477/EEC.

${ }^{18}$ UČUR, Marinko, Nomotehnika, Veleučilište, Rijeka, 2007. dan i na drugi čimbenik, bitan kao nomotehničko određenje propisa. Trebalo je obuhvatiti sve radnike koji su radili u radnom odnosu kod pravnih prednika poslodavaca i bili izloženi azbestu.

Azbest je riječ grčkog podrijetla (prevodi se kao neugasli mineral vrsta "nesagorljivog" minerala, magnezijev silikat končastog sastava....). ${ }^{19}$ Radnici koji su svakodnevno, dulji niz godina izloženi velikim koncentracijama azbestne prašine obolijevaju od azbestoze, "kao teške i kancerogene bolesti, a manifestira se nakon 10 i više godina nakon izloženosti azbestu". ${ }^{20}$ Ima tvrdnji da je azbestoza nemaligna bolest, kancerogene bolesti koje izaziva azbest su dokazano karcinomi pluća, maligni mezoteliomi dok ne postoje posve uvjerljivi dokazi (medicina zasnovana na dokazima) da je i karcinom grkljana sigurno povezan s izloženošću azbestu. Trebalo je Zakonom obuhvatiti i radnike koji su bili izloženi azbestu radeći u t.d. prednicima (u ovom Zakonu) navedenih poslodavaca, i kada "azbest kao materijal nije bio zabranjen..." (radi se o "Azbestu“ Ploče) i kada su obolijevanja bila puno veća. Postupno je iz proizvodnje „izbacivan“ azbest i „uvođen supstitut" (staklena i keramička vlakna). U pogonima navedenih t.d. radile su i žene - radnice „gdje je koncentracija azbestne prašine bila najveća".

„Podaci potvrđuju da se posljedice primjene azbestne tehnologije pojavljuju nakon 10, 20 pa i 30 i 40 godina od udisaja azbestnih čestica". To je predlagatelj Zakona i u ovom slučaju uzeo u obzir. ${ }^{21}$ Naime svim oboljelima se priznaje vrijeme latencije 10, 20 i 40 godina pa i više iako nije striktno navedeno u Zakonu, ali je u provedbenom aktu i ta se činjenica uzima u obzir u sporovima. Ona će biti presudna i u potencijalnim sporovima za naknadu za obeštećenje koje će pokretati radnici koji nisu obuhvaćeni ovim Zakonom. Pri tome će se primijeniti i drugi odgovarajući propisi (navedeni u tekstu ovoga rada).

\footnotetext{
${ }^{19}$ VUKAJLIJA, Milan, Leksikon stranih reči i izraza, Beograd, 1966., str. 16; KLAIĆ, Bratoljub, Rječnik stranih riječi, Zagreb, 1962. str. 149. "primjenjuje kao materijal otporan prema vatri i kiselinama"; "... od njegovog konca izrađuju se tkanine za odijela vatrogasaca", "... služi i za izolaciju..."

${ }^{20}$ P.Z. br. 642. "Obrazloženje" - str. 1 ("Primjedbe...").

${ }^{21}$ PAVLOVIĆ, Milan, UČUR, Marinko, Zaštita na radu provedbeni propisi s komentarimma i tumačenjima, TIM press, Zagreb, 2009., str. 82., Hrvatski sabor, P.Z. br. 724 prijedlog Zakona o obeštećenju radnika profesionalno izloženih azbestu, Zagreb, 2007.
} 


\section{Konvencija broj 162 o sigurnosti prilikom upotrebe azbesta (1986.)}

Konvencija MOR-a (ILO) broj 162 (1986.) je višestrani međunarodni ugovor kojem je Republika Hrvatska stranka na temelju notifikacije o sukcesiji, a izravno se odnosi na sigurnost prilikom uporabe azbesta. Prihvaćena je 24. Iipnja 1986. u Genevi (Convention No 162 - Convention concerning safety in the use of Asbestos). ${ }^{22}$

U preambuli ove Konvencije, Opća konferencija MOR-a „poziva“ se i na ove konvencije i preporuke: o radnoj okolini (zagađenost zraka, buka, vibracija) iz 1977. g.; konvencije i preporuke o sigurnosti i zdravlju radnika iz 1981. i Konvenciju i preporuku o zdravstvenim službama na radnom mjestu iz 1985. g., Revidiranu listu profesionalnih bolesti iz 1980. g.; te Konvenciju i preporuke o profesionalnom raku iz 1974. g. i Konvenciju o davanjima u slučaju ozljede na radu i profesionalnih bolesti iz 1964. g. Pored toga, navedeno je da je Međunarodni ured rada 1984. utvrdio načela nacionalne politike i djelovanja na nacionalnoj razini u Zborniku praktičnih uputa o sigurnosti prilikom uporabe azbesta. ${ }^{23}$

Iz ovoga se vidi koliki je značaj, širina i „prostorno važenje" ove Konvencije i koja sva pitanja i odnose treba uzeti u obzir za njezinu primjenu. To je vidljivo i iz činjenice da je na istoj konferenciji donesena i Preporuka uz Konvenciju (istog naziva i broja).

Konvencija 162 o sigurnosti prilikom uporabe azbesta nije zabranila uporabu azbesta, već je utvrdila osnove u vezi sa sigurnošću uporabe azbesta, a „primjenjuje se na sve djelatnosti koje uključuju izloženost radnika azbestu tijekom rada" (članak 1., stavak 1 . Konvencije). U stavku drugom članka 1. omogućeno je da „članica koja ratificira ovu Konvenciju može... isključiti određene grane gospodarske djelatnosti ili određena poduzeća od primjene nekih odredaba ove konvencije, nakon što se uvjeri da je njihova primjena na te grane ili poduzeća nepotrebna", pri čemu „nadležna vlast mora uzeti u obzir učestalost, trajanje i stupanj izloženosti, kao i vrstu rada

\footnotetext{
${ }^{22}$ Konvencija MOR-a 162 (1986.) obvezuje Republiku Hrvatsku kao stranku (državu) na temelju notifikacije o sukcesiji od 8.10.1991. (N.N. - M.U., br. 2/94.), a objavljena je u N.N. - M.U., br.11/03.

${ }^{23}$ Konvencija MOR-a 162 (1986.) cit. ("Polazišta" ili Preambula).
}

i radne uvjete" (stavak 3. istog članka). Postupak za to propisan je na načelu tripartacije, jer vlada države o tome odlučuje "nakon savjetovanja s najreprezentativnijim organizacijama zainteresiranih poslodavaca i radnika i na temelju procjene opasnosti za zdravlje i primijenjenih sigurnosnih mjera...". ${ }^{24}$

Posebna karakteristika ove Konvencije je u definiranju pojmova: azbest, azbestna prašina, azbestna prašina koja lebdi u zraku; azbestna vlakna koja se mogu udisati; izloženost azbestu; radnici i predstavnici radnika. Nadalje, na istoj Konferenciji (72. od 24.6.1986.) utvrđena je i Preporuka br. 172 (1986.) o sigurnosti pri uporabi azbesta kojom je preporučeno državama članicama "na sve aktivnosti koje sadrže rizik od izlaganja radnika azbestu pri obavljanju dužnosti“. O potpunoj zabrani azbesta nije bilo odredbi.

Zaključuje se da je Konvencija 162 međunarodni ugovor koji je Republiku Hrvatsku obvezivao i prije 8. listopada 1991., a po pravnoj je snazi iznad Zakona. ${ }^{25}$ Konvencija nije protivna Ustavu države. Od stupanja na snagu Zakona o ratifikaciji bila je obveza iz članka 3. Konvencije: „Nacionalnim zakonima ili drugim propisima se moraju propisati mjere koje treba poduzeti za sprječavanje i kontroliranje, te zaštitu radnika od, opasnosti za zdravlje zbog profesionalne izloženosti azbestu", a ovi se moraju „povremeno revidirati u svjetlu tehničkog napretka i razvoja znanstvenih spoznaja". Pri tome "Nadležna vlast mora se savjetovati s najreprezentativnijim organizacijama zainteresiranih poslodavaca i radnika o mjerama koje treba poduzeti u svrhu primjene odredaba ove konvencije", a osigurava se zadovoljavajućim i „odgovarajućim sustavom inspekcije". ${ }^{26}$ Zaštitne i preventivne mjere odnose se i na poslodavce i na radnike (stručne

\footnotetext{
${ }^{24}$ Konvencija MOR-a (ILO, OIT) 162 (1986.) o sigurnosti prilikom uporabe azbesta: članak 1., Pravilnik o procjeni rizika - N.N., br. 112/14. Ova Konvencija je nakon ratifikacije u Skupštini SFRJ bila objavljena u "SI. listu SFRJ" - M.U." 4/89." pa se primjenjivala i na prostoru Republike Hrvatske. Sabor Republike Hrvatske je 26. lipnja 1991. godine donio Zakon o preuzimanju saveznih zakona iz oblasti radnih odnosa i zapošljavanja - N.N., br. 34/91. Republika Hrvatska postala je "strankom na temelju notifikacije o sukcesiji" i preuzela u kontinuitetu konvencije (N.N. - M.U., br. 2/94., 6/95. 3/00.), a od 8. listopada 1991.; Preporuka br. 172 (1986.) o sigurnosti pri uporabi azbesta - N.N., br. 53/91.

${ }^{25}$ Ustav Republike Hrvatske - N.N., br. 56/90.; 85/10. (proč. tekst) i 5/14., Zakon o sklapanju i izvršavanju međunarodnih ugovora - N.N., br. 28/96.

${ }^{26}$ Konvencija MOR-a 162., cit. članak 4. i 5.
} 
kontrole, metode rada, higijena na radnom mjestu, propisivanje posebnih pravila i postupaka, dozvole i dr.). Nacionalnim propisima može se ne samo ograničiti, već „potpuno ili djelomično zabraniti uporabu azbesta ili nekih vrsta azbesta ili proizvoda koji sadrže azbest u nekim radnim procesima. Uporaba krokidolita i proizvoda koja sadrže ova vlakna je zabranjena". ${ }^{27}$ Još uvijek se radi o ograničenjima.

Posebne obveze po ovoj Konvenciji imaju poslodavci u davanju određenih obavijesti nadležnim vlastima, proizvođači i dobavljači azbesta i proizvoda koji sadrže azbest, a vlast „mora propisati granice do kojih radnici mogu biti izloženi azbestu" i druge kriterije izloženosti "za ocjenu radnog okruženja“. Ističe se „nadzor nad radnim okruženjem i zdravljem radnika, informiranje i edukacija" te druga pitanja i odnosi. ${ }^{28}$

\section{Preporuka MOR-a broj 172 (1986.)}

\section{Uvod, polje primjene i definicije o sigurnosti pri uporabi azbesta}

Glavna skupština (Generalna konferencija) Međunarodne organizacije rada (MOR-a, ILO, OIT), na prijedlog Upravnog vijeća (Administrativnog savjeta), 4. lipnja 1986. na 72. sjednici u Ženevi, donijela je Preporuku broj 172. o sigurnosti pri uporabi azbesta, uz Konvenciju 162 (1986.) o sigurnosti prilikom upotrebe azbesta i drugih odgovarajućih konvencija i preporuka „trebalo bi da se primjenjuju na sve aktivnosti sa rizikom izlaganja radnika azbestu prilikom obavljanja dužnosti“. ${ }^{29}$

\footnotetext{
${ }^{27}$ Isto: članak 9., 10. i 11. "Razmekšavanje bilo kojeg oblika azbesta je zabranjeno". Izraz "azbest" znači vlaknasti oblik mineralnih silikata koji pripadaju metamorfnim stijenama iz skupine serpentine, to jest, klizotil (bijeli azbest) i iz skupine amfibola, to jest, aktinolit, amazit (smeđi azbest, cummingtonite - grunerit), antofilit, krokidolit (plavi azbest), termolit ili bilo koja smjesa koja sadrži jedan ili više njih"; Izraz "azbestna prašina" znači azbestne čestice koje lebde u zraku ili nataložene azbestne čestice koje se mogu naći u zraku u radnom okruženju" (članak 2., st. 1. pod (a) I (b) Konvencije) ${ }^{28}$ Isto: članak 15.-22.

${ }^{29}$ Konvencija MOR-a (ILO, OIT) br. 162 (1986.) o sigurnosti prilikom upotrebe azbesta, Ženeva, 24.6.1986. - N.N. - M.U., br. 2/94., 11/03.; Preporuka MOR-a (ILO, OIT) br. 172 (1986.) o sigurnosti pri upotrebi azbesta - N.N., br. 53/91. Konvencija i Preporuka, kako je već navedeno, a na koje se Konvencija poziva objavljene su u knjizi UČUR, Marinko, LALETA, Sandra, Konvencije MOR-a s komentarima, Pravni fakultet, Rijeka, TIM - press, Zagreb, 2007.
}

Za okvir ovog rada upućuje se i na Zbirku praktičnih uputa o sigurnosti prilikom korištenja azbesta (Međunarodni ured rada, 1984.) kojima se utvrđuju načela nacionalne politike i akcije na nacionalnom planu.

Imajući u vidu da je u pitanju pravni dokument preporuke koji ne obvezuje već "sugerira", "upućuje", "savjetuje" države-članice da svojim nacionalnim zakonodavstvom „postupa“ u skladu s preporukom, sadržaj upravo i u tom smislu „uređuje" subjekte, pitanja i odnose sigurnosti radnika pri korištenju azbesta „u skladu sa zakonodavstvom i nacionalnom praksom".

Posebno je upućeno na brigu „zapošljavanje mladih ljudi koji imaju manje od 18 godina na poslovima sa rizikom od profesionalnog izlaganja azbestu... ${ }^{130}$ Kako je azbest fibrogena prašina, izlaganje azbestu je posao s posebnim uvjetima rada te je dob uzeta u obzir još 1984 . godine u $\mathrm{RH}$, dakle rad s azbestom mlađima od 18 godina bio je zabranjen.

U stavku 2. točke I. navedeni su „poslovi sa rizikom profesionalnog izlaganja azbestu“ (prvenstveno): proizvodnja, korištenje (primjena), vađenje, popravljanje, održavanje, rušenje, transport, skladištenje i ostale aktivnosti "sa rizikom od izlaganja azbestnoj prašini koja lebdi u zraku“. Nije u pitanju zabrana.

U stavku 3. glave I. definirani su pojmovi: „,azbest", ",azbestna prašina", "azbestne prašine koje se udišu“, "izlaganje azbestu“, "radnici" (svi članovi proizvodnih kooperativa), „predstavnici radnika" (u smislu Konvencije predstavnicima radnika, 1971. godine).

\section{Opća načela}

U ovom dijelu Preporuka utvrđuje ova „opća načela":

- propisane mjere "trebalo bi da budu koncipirane..." kako bi se primjenjivale „na različite rizike... u svim gospodarskim granama";

- nadležna tijela trebala bi „periodično da preispituju propisane mjere...";

${ }^{30}$ Preporuka - cit. točka I/3. 
- nadležno tijelo trebalo bi preispitati određene mjere i "razvijati aktivnosti“ poslije konzultacija s reprezentativnim udrugama poslodavaca i „sindikata“;

- u konzultacije treba uključiti stručnjake, posebno „zdravstvene službe na radu“, pored predstavnika radnika za zaštitu na radu i drugih;

- korištenje propisane opreme (osobnih zaštitnih sredstava);

- postupanje u slučaju da radnik „napusti mjesto rada" jer je "opasno za njegov život, odnosno zdravlje";

- isključenje „štetnih mjera... u odnosu na radnika koji je bez zadnje namjere, uputio žalbu na ono što je smatrao prekršajem propisanih odredbi, odnosno ozbiljnim nedostatkom mjera koje je poduzeo, poslodavac u području sigurnosti, zdravlja radnika i radne sredine...".

\section{Mjere za sprečavanje i zaštitu}

Nadležno tijelo trebalo bi osigurati sprečavanje i kontrolu izlaganja azbestu, propisujući odgovarajuće stručne kontrole i radne metode, uključujući uvjete rada na radnom mjestu, što osigurava maksimalnu zaštitu radnika. ${ }^{31}$

Nadalje, utvrđuje se periodično utvrđivanje od nadležnog tijela: vrste azbesta, radne postupke „podvrgnuti izdavanju odobrenja ili potpuno zabranjeni (ili djelomično zabranjeni), zasnovano na „znanstvenoj procjeni rizika“.

Nadležna tijela trebaju poticati „istraživanje o tehničkim i zdravstvenim problemima" u vezi s azbestom (zamjena gdje je to moguće, kontrola zdravlja, propisivanje obavješćivanja točno određenog sadržaja); uništavanjem azbesta i azbestnih materijala i drugo. ${ }^{32}$

\footnotetext{
${ }^{31}$ Preporuka - cit. (III.10.(1).

${ }^{32}$ Propisana je obveza poslodavca da prije rušenja "napravi radni plan uz konzultiranje radnika, odnosno njihovih predstavnika, program za sprečavanje i kontrolu izlaganja radnika azbestu i dr.", a nadležna tijela trebala bi u vezi s tim pružiti odgovarajuću podršku „malim poduzećima“ i drugo.

- Preporuka - isto: cit. (III. 11. - 15.).
}

Predviđene su i ove obveze:

- prihvatiti "tehničke odredbe o prevenciji od prašine, kao i odgovarajuće radne metode "radi smanjenja izlaganja na što je moguće razumljiviji i prilično ostvarljiv nivo" (III. 16.);

- koje mjere treba poduzeti (korištenje azbesta, broj izloženih radnika, strojevi, oprema i radne metode, radna mjesta, zone aktivnosti, lokacija azbesta i drugo); (III. 17.);

- "korištenje krocidolita i proizvoda koji sadrži ovo vlakno trebalo bi da bude zabranjeno..." ili, eventualno dopušteno uz konzultacije radnika i poslodavaca..." (III. 18);

- u pravilu je zabranjena "flokaža azbesta" $\mathrm{i}$ „uvođenje izolirajućih materijala pretvorivih u azbest" (III.19.):

- proizvođači i opskrbljivači azbestom odgovorni su „za odgovarajuće stavljanje naljepnica na posude odnosno proizvode"; a trebaju da „izrade i dostave jednu tehničku listu u kojoj se navode sadržaj u azbestu, rizici za zdravlje i poduzimanje potrebnih mjera..." (III. 20.);

- uspostavljanje sustava nadzora (inspekcija) u skladu s Konvencijom o azbestu (1986.) i Konvencijom o inspekciji rada (1947.); (III. 21.);

- granice izlaganja (prema dnevnom radnom vremenu od osam sati odnosno 40 sati tjedno), mjerene, revidirane i ažurirane "u svjetlu tehnološkog napretka i razvoja znanja na tehničkom i medicinskom planu" (III. 22.);

- redovito provjeravanje i održavanje postrojenja, sustava ventilacije, opreme i zaštitnih uređaja (III. 23.);

- primjena odgovarajućih metoda u čišćenju radnih mjesta (III. 24.);

- obveza poslodavca da osigura, održava i po potrebi zamijeni „bez troškova za radnike" odgovarajuću zaštitnu opremu za disanje, kao i specijalna zaštitna odijela u konkretnim slučajevima", a radnici su "obvezni da koriste tu opremu“. To ne zamje- 
njuje mjere „higijensko-tehničke prevencije" (III. 25.);

- dekontaminacija „radnih odijela“ i zabrana nošenja kući kontaminiranih radnih odijela (III. 26.);

- stavljanje na raspolaganje radnicima izloženim azbestu "duple garderobe, lavaboa, tuševa i mjesta za odmor..." (III. 27.);

- posebna zaštita otpadaka koji sadrže azbest i azbestne prašine „ispuštene sa radnih mjesta" (III. 28.).

\section{Briga o radnom okruženju (okolini, sredini) $i$ zdravlju radnika}

Nadležno tijelo utvrđuje slučajeve u kojima poslodavac poduzima mjere: sustavne kontrole koncentracije azbestne prašine, trajanje i stupanj izloženosti radnika azbestu i kontrolu zdravlja radnika (IV. 29.). Uzimanje uzoraka i mjerenje izloženosti radnika azbestu treba biti povjereno „kvalificiranom osoblju" (IV. 30.). Osim toga, utvrđuje se obveza prema radnicima izloženim azbestu (liječnički pregledi, testovi, pretrage i dr.); (IV. 31.).

Radnici koji podliježu kontroli zdravstvenog stanja trebaju imati:

- povjerljivost „njihovih osobnih i medicinskih dokumenata";

- obavijest o ciljevima i rezultatima "kontrole“,

- pravo na odbijanje medicinskih metoda „koje bi mogle da predstavljaju povredu njegovog tjelesnog integriteta";

- pravo na „pojedinačne savjete u vezi s njihovim zdravljem i radnim mjestom na kojem se nalaze";

- pravo na drugo radno mjesto s radnog mjesta na kojem je stalno izložen azbestu (IV. 32-34.).

"Nacionalnim zakonodavstvom treba da se predvidi obeštećenje za radnike koji se razbole ili su pogođeni nekim funkcionalnim oštećenjem zbog profesionalnog izlaganja azbestu, u skladu s Konvencijom o davanjima prilikom nesreće na radu i profesionalnih bolesti“ (1964.); (IV. 35.).

"Izvodi iz kontrole radne okoline trebaju se čuvati najmanje 30 godina", a izvodi iz "kon- trole radnika ... najmanje trideset godina poslije odlaska radnika s radnog mjesta na kojem je bio izložen azbestu" (IV. 36.). Podaci se čuvaju i po prestanku poslodavca.

Multinacionalna poduzeća moraju provoditi mjere za sve radnike i objekte „bez obzira na mjesto ili zemlju u kojoj se nalaze" (IV. 39.).

\section{Informiranje i obrazovanje}

Ovaj dio Preporuke sadrži „preporuke“ o:

- poduzimanju mjera „radi unapređenja obrazovanja i informiranja svih zainteresiranih osoba za prevenciju i kontrolu rizika koju za zdravlje predstavlja profesionalno izlaganje azbestu, kao i za zaštitu od ovih vrsta rizika";

- izradi "didaktičkih vodiča“ namijenjenih poslodavcima i radnicima te ostalim osobama;

- mjerama prema radnicima (informiranje, edukacije, radne metode, korištenje individualne i kolektivne zaštitne opreme i dr.);

- štetnostima i opasnostima „od kombinacije pušenja i izlaganja azbestu";

- konkretnim mjerama i suradnji udruga poslodavaca i radnika na „izradi programa za obrazovanje, informiranje, sprječavanje, kontrolu i zaštitu u vezi s profesionalnim rizicima od izlaganja azbestu..." (V. 40. do V. 44.). ${ }^{33}$

\section{DIREKTIVE EU-a KAO VRELO PRAVA}

Direktiva Vijeća 89/391/EEZ od 12. lipnja 1989. o utvrđenju mjera za poticanje poboljšanja sigurnosti i zdravlja radnika na radu predstavlja okvirnu direktivu o pitanjima i odnosima zaštite zdravlja i sigurnosti na radu. ${ }^{34}$

I ovdje se radi "o minimalnim zahtjevima za poticanje poboljšanja, posebno u radnom okruženju, kako bi se zajamčila viša razina zaštite sigurnosti i zdravlja radnika“; "budući da je poznato da radnici tijekom svog radnog vijeka na

\footnotetext{
${ }^{33}$ UČUR, Marinko, LALETA, Sandra, Konvencije MOR-a s komentarima, TIM-press, Zagreb, Pravni fakultet, Rijeka, 2007.

${ }^{34}$ "SL. L., br. 183, 29.6.1989.
} 
radnom mjestu mogu biti izloženi djelovanju opasnih čimbenika iz okoliša“ i o „okvirnoj direktivi koja bi služila kao osnova za određenje direktiva koje bi pokrivale sve rizike povezane sa sigurnošću i zdravljem na radnom mjestu“; "budući da su države članice odgovorne za poticanje poboljšanja sigurnosti i zdravlja radnika na svojem državnom području“; "budući da je pojava nesreće na poslu s profesionalnih bolesti još uvijek previsoka... moraju se bez odlaganja uvesti preventivne mjere..."; "budući da je poboljšanje sigurnosti higijene i zdravlja radnika na radu cilj koji ne bi smio biti podređen isključivo ekonomskim razlozima"; „budući da su poslodavci obvezni informirati se o najnovijem tehnološkom i znanstvenom napretku koji se odnosi na oblikovanje radnog mjesta...o prednostima u poduzeću" i drugo. ${ }^{35}$

„Države članice poduzimaju sve potrebne korake kako bi osigurale da poslodavci, radnici i predstavnici radnika podliježu pravnim propisima potrebnim za provedbu ove Direktive“ i "osiguravaju primjerenu kontrolu i nadzor" ${ }^{36}$

Slijede odredbe o "obvezama poslodavaca": „Dužnost poslodavca je osigurati sigurnost i zdravlje radnika u svakom aspektu povezanom s radom", a u tim odnosima, bez obzira na to kako je organizirana zaštita na radu, važi načelo „poslodavac odgovara“. Precizno se propisuju "Opće obveze poslodavca“; ",usluge zaštite i prevencije“; „Prva pomoć, protupožarne mjere i evakuacija radnika, ozbiljna i neposredna opasnost"; "Razne obveze poslodavaca"; "obavješćivanje radnika"; „savjetovanje i sudjelovanje radnika" i "poduka radnika", a zatim odredbe članka 13. o „obvezama radnika”.

U odredbama članka 14. reguliran je „zdravstveni nadzor" i uvođenje "mjera u skladu s nacionalnim propisima i/ili praksom s ciljem osiguranja liječničkog nadzora primjerenog sigurnosnim i zdravstvenim rizicima na radnom mjestu", a u članku 15. propisana je posebna zaštita „posebno osjetljivih rizičnih skupina".

\footnotetext{
${ }^{35}$ Isto („preambula“); Direktiva „sadrži opće načelo..." o navedenim pitanjima i odnosima, ne dovodeći u pitanje druge odredbe „postojeće i buduće, koje su povoljnije za zaštitu sigurnosti i zdravlja radnika na radnom mjestu“ (članak 1. Direktive). Ovime se izričito priznaje načelo in favorem laboratores. Primjenjuje se "na sve sektore djelatnosti..." osim u "sektoru državne uprave" i druge točno određene u članku 2.

${ }^{36}$ Isto - članak 4.
}

Prema članku 16. VE je ovlašteno donositi „pojedinačne direktive“ za određena područja.

\section{Posebne direktive o azbestu}

Europski parlament još je 1976. g. donio Direktivu o ograničavanju proizvodnje i uporabe azbesta. ${ }^{37}$

Direktiva o zaštiti radnika od azbesta 83/477/ EEC izmijenjena je Direktivom 2003/18/EC kojom se određuje da se izlaganje radnika azbestu mora svesti na minimum (u svakom slučaju ispod graničnih vrijednosti). Direktiva o sveobuhvatnoj zabrani korištenja i marketingu proizvoda koji sadrže azbest (Direktiva 1999/77/EC) stupila je na snagu 1.1.2005.

Direktiva 2009/148/E7 Europskog parlamenta i Vijeća od 30. studenoga 2009. o zaštiti radnika od rizika zbog izlaganja azbestnom radu (tekst značajan za Europski gospodarski prostor); (SL. L., 330, 5.1.2010. uslijedila je nakon devet prethodnih od 1967. odnosno 1976. o: klasifikaciji svih vrsta azbesta, ograničavanju proizvodnje i uporabe azbesta; mjerama za zaštitu okoline od onečišćenja azbestom kao i mjerama za kontrolu otpada od azbesta; zaštiti radnika od izloženosti azbestu; reklamiranju i uporabi azbesta; mjerama za zamjenu azbesta; smanjenju maksimalne dopuštene količine azbesta; zabrani uporabe svih vrsta azbestnih vlakana te zaštiti radnika od izloženosti azbestu pri radu.

Imajući u vidu da se azbest i dalje koristi (jer nije zabranjen) u nekim državama u svijetu (SAD, Rusija, Kina, Indija, Kanada), najvažnija je zabrana uvoza proizvoda koji sadrže azbest i detaljna kontrola tog postupka.

Direktiva 2009/148/EZ ističe: preventivne mjere, ograničavanje aktivnosti koje uključuju izlaganje azbestu, obavješćivanje „prilagođeno novim uvjetima rada; zabraniti aktivnosti kojima se radnike izlaže azbestnim vlaknima tijekom svih „operacija“ s azbestom; profesionalnu izloženost

${ }^{37}$ VUČINIĆ, J. i drugi, Analiza proizvodnje azbesta i posljedica na zdravlje ljudi, Sigurnost, 49 (2) 137-144 (2007); Direktiva 67/548/ EEC (1991.) o klasifikaciji svih vrsta azbesta; Direktiva 83/477/EEC (1983.) o zaštiti radnika zbog izloženosti azbestu; Direktiva 91/659/ EEC o zabrani uporabe svih vrsta azbesta; Direktiva 2003/18/EC o zaštiti radnika od izloženosti azbestu pri radu i druge. 
radnika azbestu treba smanjiti na minimum; posebno obveze poslodavca „prije početka bilo kakvog projekta uklanjanja azbesta; obavljanje „poslova rušenja ili uklanjanja azbesta", posebno s osposobljavanjem radnika, preporuke u vezi s kliničkim nadzorom izloženih radnika; mjerenje izloženosti, povremene izloženosti te izloženosti niskog intenziteta; obavijesti nadležnim tijelima i druge aktivnosti. Ovom Direktivom stavljena je izvan snage Direktiva 83/447/ EZ. Direktiva 2009/148/EZ stupila je na snagu 20.12.2009.

\section{Neka rješenja u europskoj sudskoj praksi}

Također i u europskoj sudskoj praksi ima presuđenih slučajeva u tzv. „azbestnim“ sporovima. ${ }^{38}$ Sporovi se odnose na naknadu štete odnosno odgovornosti za štetu zbog utjecaja azbesta na razvoj bolesti kod osoba izloženih azbestu. "Znakovi oboljenja uslijed izloženosti azbestu često nastupaju nakon proteka više desetljeća... Relativno je malen stupanj medicinskog shvaćanja utjecaja azbesta na zdravlje". ${ }^{39}$ Što se tiče odgovornosti, posebno je "razmatran“ pojam nepažnje („određeni stupanj nepažljivog ponašanja, odnosno izostanka pažljivog ponašanja, što dovodi do povrede određene dužnosti pažnje“) pa "odgovornost se utvrđuje u slučaju kršenja opće dužnosti dužne pažnje". Dodatni uvjet jest "nužnost da je takva specifična okolnost tuženika unaprijed poznata odnosno predvidljiva...". "...odgovornost se utvrđuje u slučaju kršenja opće dužnosti dužne pažnje, odnosno kada je tuženik bio nepažljiv te uslijed svoje nepažnje prouzročio određenu štetu tužitelju, pod uvjetom da uzrok takvoj šteti nije neznatan (too remote) te da je šteta nenadoknadiva". U drugim predmetima "dovoljno je dokazati...kako je izloženost azbestu povećala rizik oboljenja...". Nije irelevantan stav suda da postoji "rizik od azbesta u širem okolišu ili na drugom radnom mjestu...". U Republici Hrvatskoj i ta činjenica uzeta je u obzir definiranjem posrednog izlaga-

\footnotetext{
${ }^{38}$ Vidi MUDRIĆ, Mišo, Pitanje uzročnosti u azbestnim predmetima - praksa engleskih sudova, Kopaonik, Beograd, 2010.

${ }^{39}$ Isto - st. 2. „Engleski su sudovi... u azbestnim predmetima predvidjeli iznimku od standardnog uređivanja postojanja uzročnosti“.
}

nja azbestu koje se upravo odnosi na navedene situacije. Najveći broj tužbenih zahtjeva za naknadu štete u vezi s azbestnim sporovima tek (se)

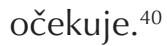

\section{PROBLEM SKLADIŠTENJA I RECIKLAŽE}

Neprekidni razvoj i napredak tehnologije omogućava veliki broj kemijskih tvari koje različito utječu na čovjekovo zdravlje i život te njegov okoliš. Mnoge od njih su toksične, zapaljive, eksplozivne (i drugih karakteristika). Jedan od tih je i azbest (u prošlosti dosta korišten u mnogim industrijskim granama). Uporaba azbesta započela je početkom 20. stoljeća (izolacija lokomotiva na paru), a u Drugom svjetskom ratu (u brodogradnji) a onda, do danas u više od 3000 različitih primjena azbesta (vatrogasni tekstil, azbestno-cementni konopci, cijevi, krovni i podni proizvodi, električni i termički izolacijski materijali i dr.). Europske države su i prije Direktive EU-a uvodile zabranu uporabe azbesta (nordijske zemlje od 1970. do 1980. g., Njemačka 1993.). Zamjena azbesta neazbestnim materijalima je dug, složen i veoma skup proces koji jedva da podnose i bogate zemlje. Sada je problem sigurnog skladištenja ili reciklaže azbestnog otpada. ${ }^{41}$

Troškovi odlaganja azbestnog otpada su veliki, a proces je opasan za radnike koji obavljaju radne operacije u vezi s tim (rukovanje i manipulacije azbestnim otpadom, sanacija opreme ili objekta, prikupljanje, pakiranje, skladištenje, tretman i poslovi konačnog odlaganja - deponiranje). Uz visoke materijalne troškove ne smiju se zanemariti troškovi prevencije i zaštite radnika koji rade navedene i druge poslove (nabava osobnih zaštitnih sredstava i dr.). Rad se izvodi u posebnom tehnološkom procesu. I tu mogu biti posljedice nakon nekoliko desetljeća,.. iako su prema sadašnjim saznanjima svedene na minimum (osobna zaštita praktički onemogućuje udisanje azbesta kada se pravilno upotrijebi). ${ }^{42}$

\footnotetext{
${ }^{40}$ Isto - str. 12.

${ }^{41}$ PETROVIĆ, Vesna i dr., Neke mogućnosti reciklaže materijala koji sadrže azbest, Zbornik radova, Zaštita na radu i zaštita zdravlja, Karlovac, 2016., str. 584-589.

${ }^{42}$ Isto.
} 


\section{OBEŠTEĆENJE RADNIKA PROFESIONALNO IZLOŽENIH AZBESTU}

Od svibnja 2019. u "saborskoj proceduri" nalazio se Prijedlog zakona o obeštećenju radnika trgovačkog društva Plobest d.d. (Ploče) prema prijedlogu Vlade Republike Hrvatske. ${ }^{43}$ U "Ocjeni stanja" toga Prijedloga istaknuto je: „U Republici Hrvatskoj azbest je imao brojnu primjenu pa se tako koristio u građevinskoj industriji, automobilskoj industriji, u brodogradnji, metalurgiji itd. Svi tipovi azbestnih vlakana (klocidolit, anozit, autofilit, tremolit, krizotil) mogu prouzročiti ozbiljne bolesti te je njihova uporaba u Republici Hrvatskoj kao i u cijeloj Europskoj uniji zabranjena. Dugotrajna izloženost može izazvati rak pluća i druge plućne bolesti”. „Specifičnosti kod izloženosti azbestu sadržane su u tome, što se znakovi oboljenja kao posljedice za zdravlje zaposlenih na poslovima s azbestom javljaju u pravilu znantno kasnije za 10 - 20 godina od udisanja azbestnih čestica". ${ }^{44}$

Ovim Zakonom bilo bi obeštećeno 510 odnosno 566 radnika koji su u razdoblju od 8. listopada 1991. godine do 21. listopada 2002. godine bili zaposleni u trgovačkom društvu Plobest d.d. i Plobest d.d. u stečaju, „zbog višegodišnje izloženosti azbestu“. "Referentno razdoblje ... počinje 8. listopada 1991. godine, a završava 21. listopada 2002. godine". ${ }^{45}$

Osnovna djelatnost trgovačkog društva Plobest d.d. Ploče „bila je proizvodnja azbestnih proizvoda", a 1. ožujka 2005. brisano je iz registra.

Zakonom se priznaje obeštećenje radniku navedenog trgovačkog društva „,koji je bio u radnom odnosu (u t.d.) od 8. listopada 1991. godine do 21. listopada 2002. godine i koji je najmanje 5 godina (u istim t.d.) radio izložen azbestu,

${ }^{43}$ Hrvatski sabor, P.Z. br. 672, Prijedlog zakona o obeštećenju radnika trg. društva Plobest d.d., Klasa: 022-03/19-01/81, Urbroj: 6519-02, Zagreb, 10. svibnja 2019.; Ustav Republike Hrvatske - N.N., br. 85/10., proč. tekst i 5/14. Odluka Ustavnog suda Republike Hrvatske; Poslovnik Hrvatskog sabora - N.N., br. 81/13., 113/16., 69/17. i 29/18.

${ }^{44}$ Isto - P.Z. br. 672., str. 1.

${ }^{45}$ Isto -2 . Referentno razdoblje određeno je „danom proglašenja neovisnosti Republike Hrvatske 8. listopada 1991. godine, zaključno sa 21. listopada 2002. godine, odnosno danom prije otvaranja društva Novi Plobest d.o.o., Ploče ... koje nije registrirano za rad s azbestom." odnosno njegovom nasljedniku (u daljem tekstu: radnik)". ${ }^{46}$

Drugi subjekt ovih odnosa je Fond za zaštitu okoliša i energetsku učinkovitost, određen u članku 2., st. 2. ovog Zakona, a preuzima „obvezu osiguranja sredstava za isplatu obeštećenja, kao i obvezu obeštećenja na temelju ovog Zakona". ${ }^{47}$

Ovo je „pojedinačni“ propis, Zakon za "konkretan slučaj" i odnose "uređuje obeštećenje radnika t.d. "Plobest d.d. Ploče". Određeni su adresati, a u obrazloženju za donošenje Zakona navedeno je da se radi o 510 (566) radnika na koje se Zakon primjenjuje. Određena je i „svota obeštećenja u iznosu od 219.000,00 kuna“ koja se „isplaćuje obročno kroz razdoblje od tri godine od dana pravomoćnosti rješenja..." svakom radniku. ${ }^{48}$

„Tražbina dospjele novčane naknade koja nije isplaćena zbog smrti osobe kojoj je ista priznata, nasljeđuje se". ${ }^{49}$

Bez obzira što uređuje konkretan "slučaj i odnos", Zakon ima sve objektivne pretpostavke (karakteristike) nomotehničkog stvaranja pravnih propisa (pravna osnova, donosilac, naziv (ime), sadržaj, postupak, vremensko i prostorno važenje).

\section{Postupak za ostvarivanje prava}

Zakon uređuje „postupak i tijela nadležna za rješavanje obeštećenja”. „U postupku ostvarivanja prava na obeštećenje prema ovome Zakonu primjenjuju se odredbe Zakona o općem upravnom postupku“. ${ }^{50}$

Zahtjev podnosi radnik „koji je bio u radnom odnosu u trgovačkim društvima (koje određuje Zakon) od 8. listopada 1991. godine do 21. listo-

\footnotetext{
${ }^{46}$ P.Z. br. 672. - cit. članak 1. i 2.; Zakon o obeštećenju - N.N., br. $13 / 20$.

${ }^{47}$ Isto: članak 4

${ }^{48}$ Isto: članak 3. Prvi obrok svote obeštećenja isplatit će se do kraja 2020. godine u iznosu od 73.000,00; drugi obrok od 73.000,00 kuna do kraja 2021. godine i treći obrok od 73.000,00 kuna do kraja 2022. godine.

${ }^{49}$ Isto: članak 3., st. 2. Vidi Zakon o nasljeđivanju - N.N., br. 48/03. do $33 / 15$.

${ }^{50}$ Isto - članak 5., st. 5. Vidi Zakon o općem upravnom postupku - N.N., br. 47/09.
} 
pada 2002. godine i koji je najmanje pet godina u istim društvima radio izložen azbestu..."

Uz zahtjev radnik podnosi i "dokaze o ispunjavanju uvjeta za podnošenje zahtjeva za obeštećenje". Dokaz o radnom odnosu pribavlja radnik od poslodavca ili iz matične evidencije MIO, za propisano razdoblje $(x / 1991$. do $x / 2002$. godine). To se odnosi i na dokaz „da je najmanje pet godina u istim društvima radio izložen azbestu". To su svi pojedinačni akti (ugovor o radu, odluke, rješenja iz kojih je vidljivo radno mjesto (poslovi i radni zadaci), autonomni opći akti poslodavca, prijave o osiguranju i drugi dokazi iz propisanih evidencija o radniku). ${ }^{51}$ Potpuno je nepotrebno opterećivati radnika da pribavi dokaze.

Radnik podnosi zahtjev Fondu za zaštitu okoliša i energetsku učinkovitost „u roku od 90 dana od dana stupanja na snagu ovoga Zakona“. ${ }^{52} \mathrm{Na}$ rokove i njihovo računanje (i eventualno propuštanje) pazi i aktivna i pasivna stranka u postupku uz primjenu odgovarajućih odredbi Zakona o općem upravnom postupku..$^{53}$ "Zahtjev mora sadržavati dokaz o ispunjavanju uvjeta...". ${ }^{54}$

Kada zaprimi zahtjev radnika za obeštećenje, Fond za zaštitu okoliša i energetsku učinkovitost „donosi rješenje u roku od 30 dana od dana zaprimanja zahtjeva". ${ }^{55}$

„Protiv rješenja... dopuštena je žalba o kojoj rješava Povjerenstvo za žalbe" (članak 5., st. 2. Zakona) koje se sastoji od tri člana („,predstavnik ministarstva nadležnog za financije, ministarstva nadležnog za zaštitu okoliša i predstavnik Fonda za zaštitu okoliša i energetsku učinkovitost" članak 5., st. 3. Zakona). "Članove Povjerenstva za žalbe ... imenuje Vlada Republike Hrvatske..., u roku od 30 dana od dana stupanja na snagu ovog Zakona" (članak 5., st. 3. i 4. i članak 6. Zakona).

\footnotetext{
${ }^{51}$ Pretpostaviti je da te podatke ima Fond za zaštitu okoliša i energetsku učinkovitost odnosno Ministarstvo zaštite okoliša i energetike, jer u P.Z. br. 672. piše da se radi o 510 (566) radnika u navedenim t.d. i da su „višegodišnje (bili) izloženi azbestu“. Uostalom, u skladu sa Zakonom o općem upravnom postupku koristit će se i druga "dokazna sredstva“. Kada je u pitanju profesionalna bolest, podatke imaju Zavodi (zdravstvenog odnosno mirovinskog osiguranja).

${ }^{52}$ Zakon - cit. članak 2., st. 2

${ }^{53} \mathrm{ZUP}$ - cit. odredbe o rokovima: članak 79.-82.

${ }^{54}$ Zakon - cit. članak 2., st. 3.

${ }^{55}$ Isto: članak 5., st. 1.
}

„Protiv rješenja Povjerenstva za žalbe može se pokrenuti upravni spor" ${ }^{56}$

Prema dostupnim podacima "Plobest" d.d. Ploče i "Plobest" u stečaju "sljedbenici“ (pravni sljednici) su tvornice „Azbest" Ploče.

I prije 1990. godine (kada je Plobest Ploče registriran u Trgovačkom sudu u Splitu (I/90) radnici su bili izloženi velikim koncentracijama azbesta. ${ }^{57}$

\section{ZAKLJUČAK}

Iz ovog rada proizlaze sljedeći zaključci:

- Zabranjen je rad s azbestom u proizvodnji. Posljedice izloženosti riziku rada s azbestom su evidentne, a za brojne radnike pogubne. $S$ azbestom se ne radi, ali je ostao u ugrađenim (i izgrađenim) objektima, instalacijama i predmetima. To će se posebno osjetiti u uklanjanju, skladištenju i uništavanju toga materijala. To će raditi radnici koji budu obavljali radne operacije u vezi s tim. Bez obzira na sve mjere i aktivnosti u preventive, posljedice, istina u manjoj mjeri, osjetit će se i nakon nekoliko desetljeća. Za one radnike koji su radili i bili izloženi azbestu traži se "rješenje" u novčanim naknadama kako bi bili obeštećeni zbog posljedica navedenog rizika. To je neimovinsko (nematerijalna) šteta jer su ugroženi životi i zdravlje tih radnika, čime je povrijeđeno pravo osobnosti, kao temeljno ljudsko pravo (pravo čovjeka). Restitucio in integrum je nemoguće.

- U Republici Hrvatskoj na snazi su konvencije MOR-a (po pravnoj snazi iznad zakona), direktive EU-a (preuzete u pravni sustav države), tri zakona i nekoliko podzakonskih (provedbenih) propisa o tim pitanjima i odnosima. Nažalost, zakasnila je preventiva u svim dimenzijama.

- Propisi uređuju obvezni zdravstveni nadzor radnika profesionalno izloženih azbestu,

\footnotetext{
${ }^{56}$ Isto: članak 5., st. 6.

${ }^{57}$ "Većina profesionalno oboljelih radnika je umalo ili zbog zdravstvenih razloga promijenilo radnu i životnu sredinu. Prema tim ljudima Zakon čini veliku nepravdu..." Isto („Provedeno savjetovanje“... str. 1., Zoran Marušić).
} 
obeštećenje radnika profesionalno izloženih azbestu, uvjete za ostvarivanje prava na starosnu mirovinu radnika profesionalno izloženih azbestu, ali i obeštećenja radnika koji su radili u točno određenim trgovačkim društvima koja su prestala postojati. Određeni su subjekti u tim odnosima (adresati i drugi). Propisan je "kompliciran" postupak (s kratkim rokovima) i niske novčane naknade koje trebaju značiti obeštećenja radnika. Nažalost, mnogi to nisu dočekali zbog smrti kao posljedice azbestoze i drugih neizlječivih bolesti izazvanih azbestom. Problem nije riješen, a pogotovo ne prema načelu jednakosti u pravima i pred zakonom. U tom smislu naknada mora biti jednaka jer su posljedice jednake i to bez obzira kada je uzrok počeo (nastao).

\section{LITERATURA}

Direktiva Vijeća 89/391/EEZ od 12. lipnja 1989. o uvođenju mjera za poticanje poboljšanja sigurnosti i zdravlja radnika na radu (SL. L. 183, 29.6.1989.)

Direktiva o sveobuhvatnoj zabrani korištenja i marketinga proizvoda koji sadrže azbest (1999/77/EC)

Konvencije MOR-a 162 (1986) o sigurnosti prilikom uporabe azbesta, N.N. - M.U., br. 11/03.

Laleta, S., Senčur Peček, D.: Atipični rad - izazovi zaštite od psihosocijalnih rizika i stresa na radu i u vezi s radom, Sigurnost, 59, 2017., 4, 315-330.

Mudrić, M.: Pitanje uzročnosti u azbestnim predmetima - praksa engleskih sudova, Kopaonik, Beograd, 2010.
Pavlović, M., Učur, M.: Zaštita na radu - provedbeni propisi s komentarimma i tumačenjima, TIM press, Zagreb, 2009.

Petrović, V. i dr.: Neke mogućnosti reciklaže materijala koji sadrže azbest, Zbornik radova, Zaštita na radu i zaštita zdravlja, Karlovac, 2016., str. 584-589.

Učur, M.: Nomotehnika, Veleučilište u Rijeci, Rijeka, 2007.

Učur, M., Laleta, S.: Konvencije Međunarodne organizacije rada, s komentarima, Pravni fakultet, Rijeka, TIM-press, Zagreb, 2007

Ustav Republike Hrvatske, N.N., br. 56/90., 85/10. (proč. tekst) i 5/14.

Vučinić, J. i drugi: Analize proizvodnje azbesta i posljedice na zdravlje ljudi, Sigurnost, 49, 2007., 2, 137-144.

Zakon o obeštećenju radnika profesionalno izloženih azbestu, N.N., br, 79/07., 139/10., 111/18.

Zakon o obeštećenju radnika trgovačkog društva Salonit d.d. u stečaju Vranjic, N.N., br. $13 / 20$.

Zakon o obeštećenju radnika trgovačkog društva Plobest d.d., N.N., br. 13/20.

Zakon o radu, N.N., br. 93/14., 127/17., 98/19.

Zakon o zaštiti na radu, N.N., br. 71/14., 118/14., 94/18., 96/18.

Zakon o općem upravnom postupku, N.N., br. 47/09.

Zakon o obveznim odnosima, N.N., br. 35/05. do 29/18. 


\section{ISSUES AND CONSEQUENCES OF THE RISK OF EXPOSURE TO ASBESTOS}

SUMMARY: In numerous companies asbestos was used in the production or realization of the registered business activity, so workers working for these employers were exposed to the risk of the consequences of such work. For some of these workers, the consequences were devastating because asbestosis and other diseases deteriorated their health. Many employers closed down their businesses and some of their legal successors have been out of business since 2005 when asbestos was banned. A serious problem (large number of social cases) is how to compensate (if at all possible) workers who have been exposed to asbestos. States act as the "guarantor" of payment of cash benefits as a form of compensation. The Republic of Croatia is bound by national and regional regulations (ILO Conventions, EU directives), as well as by national regulations governing these issues and relations. The regulations are in force and they form the legal basis in often elaborate and demanding court processes in which financial considerations determine the resolution. Namely, consequences of exposure to asbestos can occur even as late as 30 or 40 years after exposure. The aim of this paper is to shed light on the gravity of the social and legal aspects of this issue.

Key words: asbestos exposure, consequences, compensation, regulations and relations

Professional paper Received: 2020-03-31

Accepted: 2020-07-03 